\title{
AKTUALISASI HIDDEN CURRICULUM PENDIDIKAN AGAMA ISLAM DAN IMPLIKASINYA DALAM PEMBENTUKAN SIKAP SOSIAL SISWA
}

\author{
Aqmarina Bella Agustin ${ }^{1}$, Sukiman ${ }^{2}$ \\ UIN Sunan Kalijaga, Yogyakarta \\ aqmarinabellaagustina@gmail.com ${ }^{1}$, sukiman@uin-suka.ac.id ${ }^{2}$
}

\begin{abstract}
ABSTRAK
Sikap sosial merupakan salah satu nilai karakter yang harus dimiliki setiap siswa sebagai bekal dalam menjalani kehidupan bermasyarakat untuk mewujudkan kondisi masyarakat yang rukun dan damai. Mata pelajaran Pendidikan Agama Islam (PAI) memiliki peran yang sangat strategis dalam pembinaan sikap sosial kepada peserta didik melalui pengembangan kurikulum tersembunyi PAI. Penelitian ini bertujuan untuk menganalisis implementasi kurikulum tersembunyi Pendidikan Agama Islam (PAI) di SMP Negeri 9 Yogyakarta dan implikasinya terhadap pembentukan sikap sosial peserta didik. Jenis penelitian yang digunakan adalah deskriptif analitik kualitatif. Subjek penelitian dipilih secara purposive yaitu meliputi kepala sekolah, wakil kepala sekolah bidang kesiswaan, guru PAI, guru bimbingan dan konseling, dan peserta didik. Teknik pengumpulan data dilakukan melalui wawancara, observasi, dan dokumentasi kemudian dianalisis menggunakan tahapan reduksi, penyajian, penarikan kesimpulan / verifikasi. Uji validitas data dengan menggunakan triangulasi sumber dan teknik. Hasil penelitian menyimpulkan bahwa penerapan kurikulum tersembunyi PAI di SMP Negeri 9 diwujudkan dalam bentuk penerapan sistem organisasi, sosial, dan budaya. Penerapan kurikulum Tersembunyi PAI berimplikasi pada pembentukan sikap sosial peserta didik yang ditunjukkan dengan sikap menghargai orang lain, tidak pilih-pilih dalam bersahabat, terbiasa tersenyum, menyapa, dan menyapa semua orang, jujur, disiplin, bertanggung jawab, membantu teman yang membutuhkan, dan merawat orang lain.
\end{abstract}

Kata Kunci: Hidden curriculum, Pendidikan Agama Islam, sikap sosial 


\title{
THE ACTUALIZATION OF HIDDEN CURRICULUM IN ISLAMIC EDUCATION COURSE IN ESTABLISHING SOCIAL ETITUDE FOR STUDENTS
}

\author{
Aqmarina Bella Agustin ${ }^{1}$, Sukiman ${ }^{2}$ \\ UIN Sunan Kalijaga, Yogyakarta \\ aqmarinabellaagustina@gmail.com ${ }^{1}$, sukiman@uin-suka.ac.id ${ }^{2}$
}

\begin{abstract}
Social attitude is one of the character values that every student must have as a provision in living life in the community to materialize a harmonious and peaceful community condition. The subjects of Islamic Religious education (PAI) have a very strategic role in the cultivation of social attitudes to the students through the development of the PAI hidden curriculum. This research aims to analyze the implementation of the hidden curriculum of Islamic Religious Education (PAI) at State Junior High School 9 Yogyakarta and its implications for the formation of learners ' social attitudes. This type of research used is qualitative descriptive-analytic. The research subject is chosen purposive, which includes the headmaster, vice-principal of student affairs, PAI teacher, guidance and counseling teacher, and learners. Data collection techniques are conducted through interviews, observations, and documentation and then analyzed using the reduction, presentation, conclusion/verification stages. Test the validity of data using the triangulation of resources and techniques. The results concluded that the implementation of the hidden curriculum of PAI in SMP Negeri 9 was realized in the form of implementing the organizational, social, and cultural system. The implementation of the Hidden curriculum of PAI implicates the formation of learners ' social attitudes demonstrated by the respectful attitude of others, not picky in friendship, accustomed to smiles, greetings, and greet everyone, honestly, disciplined, responsible, helping friends in need, and caring for others.
\end{abstract}

Keywords: Hidden curriculum, Islamic Religious Education, social attitude. 


\section{PENDAHULUAN}

Mata pelajaran Pendidikan Agama Islam (PAI) memiliki peran yang sangat strategis untuk ikut berperan serta dalam proses penanaman nilai-nilai akhlak/karakter pada peserta didik (Su'dadah, 2014; Masykur, 2015; Indrawan, 2016). Hal ini sesuai dengan fungsi dan tujuan Pendidikan agama di sekolah sebagaimana yang disebutkan dalam Peraturan Pemerintah Nomor 55 Tahun 2007, yaitu: "(1) Pendidikan agama berfungsi membentuk manusia Indonesia yang beriman dan bertakwa kepada Tuhan Yang Maha Esa serta berakhlak mulia dan mampu menjaga kedamaian dan kerukunan hubungan inter dan antarumat beragama", (2) Pendidikan agama bertujuan untuk berkembangnya kemampuan peserta didik dalam memahami, menghayati, dan mengamalkan nilai-nilai agama yang menyerasikan penguasaannya dalam ilmu pengetahuan, teknologi dan seni." Rumusan tujuan tersebut menunjukkan bahwa Pendidikan Agama tidak hanya semata-mata menekankan pada pembentukan individu yang saleh secara vertikal saja (hubungan manusia dengan Tuhan), namun juga saleh secara horizontal. Kesalihan secara horizontal diwujudkan dalam kemampuan manusia untuk membangun hubungan sosial secara baik antara sesama manusia maupun makhluk lainnya dalam rangka mewujudkan kehidupan bersama secara harmonis dan damai (Fu'adi, 2016; Hawi \& Khoiri, 2017).

Pada dataran realitas pembelajaran Pendidikan Agama (termasuk PAI) di sekolah dinilai belum sepenuhnya mampu mencapai hasil dan tujuan sebagaimana yang diharapkan secara maksimal (Susiana, 2017). Bahkan sebagian warga masyarakat menilai pembelajaran PAI di sekolah gagal dalam membentuk karakter sosial peserta didik. Alasan mereka karena di masyarakat masih banyak dijumpai perilaku anti sosial yang dilakukan oleh kalangan peserta didik yang tidak sesuai dengan nilai-nilai karakter. Perilaku-perilaku anti sosial tersebut di antaranya adalah bersikap tidak sopan dan santun pada yang lebih tua, kasus bullying (perundungan) (Y. C. Utami, 2014; Waliyanti et al., 2018; Tjongjono et al., 2019), perkelahian antar pelajar di berbagai daerah (Malihah et al., 2015), aksi kekerasan kasus klithih di kalangan pelajar di Daerah Istimewa Yogyakarta (Sarwono, 2017), hingga tindak kekerasan pada pendidik (Dewi, 2019). Dengan fenomena seperti itu ada sebagian masyarakat yang mengusulkan penghapusan Pendidikan Agama di sekolah-sekolah dan menggantikannya dengan Pendidikan budi pekerti (Asrori, 2019).

Menyikapi problematika yang dihadapi dalam penyelenggaraan pembelajaran PAI di sekolah seperti itu, dalam konteks di Indonesia tentu tidak bijaksana kalau solusi yang ditawarkan adalah dengan menghapuskan Pendidikan Agama dari kurikulum sekolah. Alternatif solusi yang tepat adalah melakukan revitalisasi Pendidikan Agama di sekolah dengan berangkat dari persoalanpersoalan yang ada. Kegagalan Pendidikan Agama berpijak pada problem utama bahwa pendidikan agama selama ini baru sebatas pada pengembangan aspek pengetahuan, sedangkan aspek keterampilan dan sikap kurang mendapat perhatian secara memadai. Pendidikan agama yang berjalan di sekolah selama ini kurang concern (peduli) terhadap masalah mengenai cara mengubah pengetahuan agama yang bersifat kognitif menjadi sebuah makna dan nilai yang wajib diinternalisasikan ke dalam diri peserta didik melalui berbagai cara (Abdullah, 1998, p. 45). Kondisi seperti itu terjadi disebabkan banyak faktor, di antaranya adalah kurangnya alokasi waktu dan pengelolaan kurikulum PAI di sekolah (Manizar, 2018). Kurikulum merupakan komponen penting yang digunakan sebagai acuan dalam rencana pembelajaran. Harold yang dikutip oleh Hidayat 
menyatakan "Kurikulum sebagai suatu rangkaian pengalaman yang memiliki kemanfaatan maksimum bagi anak didik dalam mengembangkan kemampuannya agar dapat menyesuaikan dan menghadapi berbagai situasi kehidupan." (Hidayat, 2011, p. 8) Oleh karena itu, kurikulum harus dirancang dan dikelola sebaik mungkin demi melangsungkan pendidikan yang sesuai dengan tujuan yang ingin dicapai.

Kurikulum memiliki berbagai macam jenis, di antaranya ada kurikulum tertulis (dokumen kurikulum), kurikulum aktual (implementasi kurikulum tertulis), dan kurikulum tersembunyi (hidden curriculum) (Sukiman, 2015, p. 4). Hidden curriculum merupakan kurikulum yang memiliki aspek di luar kurikulum tertulis dan berfungsi untuk memberikan pemahaman mendalam tentang kepribadian, norma, nilai, keyakinan yang tidak dijelaskan secara menyeluruh dalam kurikulum formal (Hidayat, 2011, p. 82). Hidden curriculum yang berisikan pengalaman peserta didik di sekolah yang bersumberkan dari apa yang mereka lihat, dengar, serta alami di lingkungan sekolah menjadi salah satu faktor dalam pembentukan karakter peserta didik (Caswita, 2013, p. 49). Oleh karena itu, kurikulum tersembunyi merupakan kurikulum yang cukup signifikan dalam membentuk sikap dan karakter peserta didik (Pratiwi, 2017, p. 233).

Seorang guru PAI dalam proses pembelajaran seharusnya tidak hanya terfokus dalam kurikulum yang dipelajari saja (kurikulum tertulis), namun juga memperhatikan kurikulum tersembunyi. Dengan memanfaatkan keberadaan hidden curriculum PAI di sekolah secara optimal diharapkan dapat membantu tercapainya tujuan pembelajaran PAI dalam membentuk karakter peserta didik secara lebih optimal (Novitasari, 2017). Dengan memperhatikan kurikulum tersembunyi, pembelajaran PAI tidak akan hanya berorientasikan pada aspek pengetahuan (kognitif) saja, akan tetapi juga pada pengembangan aspek keterampilan dan sikap (perilaku). Banyak hal yang dapat dilakukan sekolah dalam melaksanakan kurikulum tersembunyi, di antaranya adalah kebiasaan sekolah menerapkan disipilin terhadap peserta didiknya, ketepatan waktu dalam memulai pembelajaran, cara penyampaian dan perilaku guru, lingkungan sekolah yang rapi, tertib, bersih, dan asri. Hal-hal tersebut dapat mempengaruhi cara berpikir dan perilaku peserta didik (Lubis, 2015, p. 76).

Terdapat beberapa penelitian tentang hidden curriculum yang dilakukan peneliti sebelumnya. (Lubis, 2015) meneliti tentang tema "Hidden Curriculum dan Pembentukan Karakter (Studi Kasus di Madrasah Aliyah Pembangunan UIN Jakarta)". (Khuzaimah, 2018) meneliti tentang "Implementasi Nilai-Nilai Pendidikan Multikultural dalam Pembelajaran PAI (Telaah Terhadap Hidden Curriculum di SMAN 1 dan SMAN 2 Grabag Tahun 2018)". (Cholisoh, 2019) meneliti tentang "Analisis Implementasi Hidden Curiculum dalam Pendidikan Karakter: Studi Kasus SD Islam Al-Syukro Universal Kota Tanggerang Selatan”. (Fariha \& Nurani 2017) melakukan penelitian tentang "Internalisasi Nilai-Nilai Keislaman dalam Skema Hidden Curriculum di MTS Nurul Huda Medini Demak". Persamaan antara penelitian ini dengan penelitian-penelitian sebelumnya adalah sama-sama menjadikan hidden curriculum sebagai kajian utama dalam fokus penelitian. Perbedaanya adalah penelitian terdahulu mengungkap implementasi hidden curriculum ke dalam kegiatan-kegiatan terprogram seperti kegiatan ekstrakurikuler dan pembiasaan keagamaan, dalam membentuk sikap multikultural siswa. Sedangkan penelitian ini lebih fokus melihat kaitan antara pengembangan hidden curriculum dengan pembentukan sikap sosial peserta didik yang tergambar melalui sistem organisasi, sistem sosial, 
dan sistem budaya yang ada di Sekolah Menengah Pertama Negeri (SMP N) 9 Yogyakarta.

SMP Negeri 9 merupakan salah satu sekolah negeri di Kota Yogyakarta yang mengembangkan kurikulum tersembunyi (hidden curriculum) untuk mendukung pembelajaran keagamaan di luar kurikulum tertulis. Selain itu, sekolah ini merupakan salah satu sekolah model di Yogyakarta yang menerapkan pembelajaran PAI berbasis afeksi. Pelaksanaan PAI berbasis afeksi dapat dilakukan dengan cara memberikan materi khusus tentang pengembangan sikap atau dengan memasukkan unsur-unsur afeksi ke dalam setiap proses pembelajaran yang dilaksanakan di sekolah (hidden curriculum) (Yaqin, 2011, p. 198). Berdasarkan hasil wawancara peneliti dengan kepala sekolah, penerapan afeksi di sekolah ini tidak hanya dilaksanakan berdasarkan instrumen pembelajaran yang sudah ada, akan tetapi sekolah juga berusaha untuk memberikan lingkungan sekolah yang sesuai dengan nilai-nilai moral (Sugiharjo, 2019). Melihat bagaimana sekolah mengembangkan kurikulum PAI dalam membentuk sikap peserta didik, peneliti tertarik mengkaji lebih lanjut mengenai cara sekolah membentuk sikap khususnya sikap sosial pada peserta didik melalui kurikulum tersembunyi (hidden curriculum) PAI yang terintegrasi ke dalam sistem organisasi, sistem sosial, dan sistem budaya di sekolah.

Berdasarkan latar belakang yang telah dikemukakan, maka permasalahan yang dibahas dalam penelitian ini meliputi dua hal, yaitu: (1) bagaimana bentukbentuk aktualisasi kurikulum tersembunyi (hidden curriculum) PAI dalam membentuk sikap sosial peserta didik di SMP Negeri 9 Yogyakarta? dan (2) bagaimana implikasi pelaksanaan hidden curriculum PAI dalam membentuk sikap sosial siswa di SMP Negeri 9 Yogyakarta? Tujuan peneliatian ini adalah: (1) untuk mengetahui dan menjelaskan bentuk-bentuk hidden curriculum PAI di SMP Negeri 9 Yogyakarta, dan (2) untuk mengetahui dan menjelaskan implikasi pelaksanaan hidden curriculum PAI dalam membentuk sikap sosial peserta didik di SMP Negeri 9 Yogyakarta.

Hasil penelitian ini diharapkan memberikan manfaat secara teoretis maupun praktis. Manfaat secara teoretis hasil penelitian ini dapat memberikan wawasan dan memperkaya khazanah keilmuan PAI khususnya tentang aktualisasi hidden curriculum dalam pembelajaran PAI. Secara praktis, hasil penelitian ini dapat digunakan sebagai bahan masukkan bagi sekolah dalam rangka pengembangan sikap sosial peserta didik melalui hidden curriculum PAI. Penelitian ini juga diharapkan dapat menjadi rujukan bagi guru PAI dalam mendidik dan mengarahkan peserta didik sehingga mampu menerapkan nilai-nilai sosial secara maksimal melalui hidden curriculum PAI.

\section{METODE PENELITIAN}

Jenis penelitian yang digunakan dalam penelitian ini adalah penelitian kualitatif deskriptif analitik (Suyanto, 2005, p. 171). Metode penelitian ini bermaksud untuk memahami fenomena tentang apa yang dialami oleh subjek penelitian, misalnya perilaku, persepsi, motivasi, tindakan, dan lain-lain, secara holistik, dan dengan cara deskripsi dalam bentuk kata-kata dan bahasa, pada suatu konteks khusus yang alamiah dan dengan memanfaatkan berbagai metode alamiah (Moloeng, 2014, p. 6). Pada penelitian ini, peneliti berusaha untuk mengekspolari secara mendalam pelaksanaan kurikulum tersembunyi PAI dalam membentuk sikap sosial peserta didik di SMP Negeri 9 Yogyakarta. 
Penetapan subjek penelitian dalam penelitian ini menggunakan metode purposive sampling (Creswell, 2014, p. 171). Subjek penelitian adalah kepala sekolah, guru PAI, peserta didik, wakil kepala sekolah bidang kesiswaan, dan guru bimbingan dan konseling (BK). Teknik pengumpulan data menggunakan teknik wawancara, observasi dan dokumentasi (Sukmadinata, 2010; Darmadi, 2013, p. 153). Jenis wawancara yang digunakan adalah wawancara tak terstruktur. Pihak-pihak yang diwawancarai di SMP Negeri 9 Yogyakarta adalah kepala sekolah, guru PAI, wakil kepala sekolah, dan guru BK untuk memperoleh data dan informasi tentang aktualisasi hidden curriculum PAI dalam pembentukan sikap sosial peserta didik. Wawancara juga dilakukan dengan peserta didik sebagai konfirmasi dan respon terhadap hidden curriculum PAI yang terjadi di sekolah dan menimbulkan efek selama berada di lingkungan sekolah. Metode observasi yang digunakan di dalam penelitian ini adalah observasi non partisipan (Margono, 2010). Metode observasi digunakan untuk menggali lebih dalam informasi terkait bentuk dan pelaksanaan hidden curriculum PAI di SMP Negeri 9 Yogyakarta serta implikasinya dalam membentuk sikap sosial peserta didik yang meliputi kegiatan pembelajaran yang sedang berlangsung di dalam maupun luar kelas, interaksi atau hubungan sosial antara guru dan peserta didik serta perilaku peserta didik di dalam dan di luar kelas. Teknik dokumen digunakan untuk mengumpulkan data tentang profil sekolah, visi dan misi, data pendidik, dan dokumentasi kegiatan pembelajaran yang berkaitan dengan hidden curriculum PAI.

Analisis data dalam penelitian ini ditempuh melalui tahapan sebagaimana yang dikembangkan oleh Miles dan Huberman yang tahapannya meliputi pengupulan data, reduksi data, penyajian data, dan kesimpulan/verifikasi (Miles \& Huberman, 1994, p. 20). Keabsahan data kemudian diuji melalui triangulasi sumber dan teknik (Nasution, 2003; Sugiyono, 2016).

\section{HASIL DAN PEMBAHASAN}

\section{Bentuk-Bentuk Hidden Curriculum PAI}

Hidden curriculum (kurikulum tersembunyi) adalah kurikulum yang memiliki aspek di luar kurikulum tertulis yang tidak menjadi bagian yang harus dipelajari namun memiliki peran besar dalam perubahan prilaku, sikap, dan moral peserta didik (Rosyada, 2007, p. 28). Pendekatan kurikulum tersembunyi dapat dilakukan melalui dua cara yakni sebagai hasil pendidikan dan sebagai praktik pendidikan (Hidayat, 2011, p. 81). Kurikulum tersembunyi sebagai hasil dan praktik pendidikan dapat diwujudkan dengan menciptakan lingkungan sekolah yang kondusif dan harmonis serta penyaluran norma dan nilai-nilai yang disampaikan oleh guru baik dalam isi pendidikan formal dan interaksi sosial yang terjadi dalam lingkungan sekolah. Martin yang dikutip oleh Mustaghfiroh menyatakan bahwa kurikulum tersembunyi merujuk pada penyaluran norma, nilai, dan kepercayaan yang disampaikan oleh guru baik dalam isi pendidikan formal dan interaksi sosial di dalam lembaga sekolah (Mustaghfiroh, 2014, p. 151). Maryani \& Fitria lebih lanjut memberikan contoh kurikulum tersembunyi, yaitu mematuhi peraturan-peraturan sekolah, melaksanakan aturan atau acara keagamaan dan mematuhi peraturan- peraturan lainnya (Maryani, 2018, p. 8).

Pada pembelajaran PAI, kurikulum tersembunyi dapat membantu mencapai tujuan PAI itu sendiri dalam membentuk sikap peserta didik. Hal ini dikarenakan kurikulum tersembunyi berfungsi memberikan pemahaman yang mendalam tentang kepribadian, norma, nilai, dan keyakinan yang tidak dijelaskan 
secara menyeluruh dalam kurikulum formal (Mustaghfiroh, 2014, p. 158). Upaya mempengaruhi perilaku peserta didik melalui pelaksanaan kurikulum tersembunyi memiliki dua aspek yakni aspek yang relatif tetap seperti ideologi, keyakinan, nilai budaya masyarakat yang mempengaruhi sekolah baik yang patut dan tidak patut diwariskan, serta aspek yang dapat berubah meliputi organisasi, sistem sosial, dan kebudayaan (Sanjaya, 2009, p. 26). Allan yang dikutip oleh Rosyada, menyatakan bahwa aspek dalam pelaksanaan kurikulum tersembunyi di antaranya: (1) Sistem organisasi, yakni suatu kebijakan penugasan bagi guru dan pengelompokan peserta didik untuk proses pembelajaran. Dalam konteks ini ada empat isu yang pantas mendapat perhatian yakni; team teaching (kebijakan dalam menugaskan guru dalam pelajaran tertentu dalam kelas yang sama), kebijakan promosi (kenaikan kelas), pengelompokan peserta didik berdasarkan kemampuan, dan pemfokusan kurikulum; (2) Sistem sosial, yakni suasana sekolah yang tergambar dari pola-pola hubungan semua komponen sekolah dalam membentuk sikap dan perilaku peserta didik seperti pola hubungan serta interaksi guru dengan tenaga administrasi dan siwa serta sebaliknya, keterlibatan kepala sekolah dalam pembelajaran dan kebebasan bagi peserta didik dalam mengikuti berbagai aktivitas sekolah; dan (3) Sistem budaya, yakni dimensi sosial yang terkait dengan sistem kepercayaan, nila-nilai, dan struktur kognitif. (Rosyada, 2007, p. 29).

SMP Negeri 9 merupakan salah satu sekolah pendidikan menengah yang terletak di Yogyakarta. SMP ini dipandang sebagai sekolah model yang menerapkan Pendidikan Agama Islam berbasif afeksi dalam membentuk budi pekerti peserta didik. Selain menerapkan pelaksanaan pembelajaran afeksi, sekolah ini juga berusaha mengimplementasikan hidden curriculum PAI untuk membantu pembentukan sikap sosial peserta didik. Implementasi hidden curriculum tersebut diwujudkan dalam tiga bentuk, yaitu sistem organisasi, sistem sosial, dan sistem budaya.

\section{Sistem organisasi hidden curriculum PAI}

Sistem organisasi dalam hidden curriculum merupakan suatu kebijakan penugasan bagi guru dan pengelompokan peserta didik untuk proses pembelajaran (Rosyada, 2007, p. 29). Proses ini menjelaskan mengenai bagaimana kebijakan sekolah dalam menaikkan peserta didik ke kelas berikutnya, bagaimana sekolah mengelompokkan peserta didik untuk pembelajaran, dan bagaimana pengaturan guru dalam mengajar sesuai dengan latar belakangnya.

Kebijakan sekolah untuk kenaikan kelas peserta didik di SMP Negeri 9 Yogyakarta dilakukan sesuai dengan aturan yang ada. Syarat-syarat yang diterapkan oleh sekolah dalam mempromosikan peserta didik (kenaikan kelas) dilakukan dengan mengikuti dokumen yang ada pada KTSP. Syarat-syarat tersebut di antaranya tidak boleh ada NK (nilai kurang) lebih dari dua dan kehadiran tanpa keterangan tidak boleh lebih dari lima persen. Pada kebijakan kenaikan kelas peserta didik, poin akademik juga menjadi acuan dalam memutuskan kenaikan peserta didik, akan tetapi poin sikap juga turut membantu di mana indikator sikap minimal harus B.

Kebijakan pengelompokan peserta didik yang dilakukan di SMP Negeri 9 ini dilakukan secara normative dan bersifat inklusif. Pengelompokan peserta didik pada masing-masing kelas dilakukan dengan rata atau seimbang, di mana setiap kelas harus ada berapa persen peserta didik yang mahir, berapa persen peserta didik yang sedang, dan berapa persen peserta didik yang memiliki kemampuan di bawah rata-rata. Pengelompokan seperti ini 
dilakukan agar tidak terjadi kesenjangan dan eksklusifisme peserta didik pada masing-masing kelas.

Kebijakan pembagian tugas mengajar guru dilakukan secara profesional. Pihak sekolah dalam menugaskan guru didasarkan pada latar belakang pendidikan yang dimiliki agar proses pembelajaran berjalan secara efektif. Kebijakan penugasan mengajar ini dilakukan agar dapat memberikan pelayanan akademik yang terbaik bagi peserta didiknya dengan menempatkan guru untuk mengajar sesuai dalam pokok-pokok bahasan yang benar-benar menjadi keahliannya.

\section{Sistem sosial hidden curriculum PAI}

Sistem sosial merupakan aspek hidden curriculum yang tergambar dari pola-pola hubungan dari seluruh komponen sekolah. Sistem sosial tergambar dalam pola hubungan serta interaksi guru dengan peserta didik, hubungan yang baik antara sesama guru dan sesama peserta didik, serta keterbukaan kesempatan bagi peserta didik dalam mengikuti berbagai aktivitas sekolah sehingga dapat membentuk sikap dan perilaku peserta didik (Rosyada, 2007, p. 30). Hubungan dan pola interaksi yang terjadi di lingkungan sekolah sebagai aspek sosial hidden curriculum merupakan penentu dalam menciptakan suasana sekolah yang nyaman dan harmonis sehingga dapat berpengaruh pada perkembangan sikap peserta didik. Hal ini dikarenakan interaksi merupakan aktivitas yang selalu ada dan tidak dapat dihindari sekalipun di sekolah seperti halnya yang terjadi saat proses pembelajaran (Sardiman, 1986, p. 14). Interaksi antara peserta didik dengan guru merupakan interaksi yang utama ketika peserta didik berada di lingkungan sekolah. Peserta didik mengalami proses pembelajaran dari guru yang merupakan implementasi dari kurikulum formal (tertulis). Akan tetapi, melalui proses pembelajaran yang telah ditetapkan itu peserta didik juga akan mempelajari hal lain yang tidak direncanakan atau dengan kata lain merupakan hasil sampingan yang merupakan implementasi dari hidden curriculum. Bentuk interaksi guru dan peserta didik di SMP Negeri 9 untuk mempengaruhi sikap sosial peserta didik dilakukan pada saat di dalam kelas maupun di luar kelas.

Pada saat interaksi di dalam kelas guru-guru di SMP Negeri 9 Yogyakarta menerapkan prinsip kedekatan dan interaksi secara dua arah dalam pembelajaran. Interaksi yang terjadi secara dua arah ini dapat membentuk sikap toleransi pada peserta didik. Hal ini dikarenakan dalam pola interaski dua arah dapat melatih keaktifan peserta didik dan memberikan kesempatan pada peserta didik untuk menanggapi atau menyampaikan pendapatanya. Interaksi yang terjadi secara dua arah menunjukkan bahwa komunikasi tidak hanya terfokus pada guru saja melainkan peserta didik juga memberikan respon atau timbal balik. Interaksi dua arah seringnya diterapkan melalui metode pembelajaran diskusi. Pada kegiatan diskusi, guru tidak hanya mengharapkan agar peserta didik dapat menguasai materi tetapi juga megajarkan kepada peserta didik untuk mau mendengarkan dan menghargai pendapat orang lain. Dengan demikian, melalui interaksi dua arah ini terkandung nilai-nilai sosial yakni nilai toleransi yang berusaha ditanamkan oleh guru pada peserta didik berupa menghargai pendapat atau pandangan orang lain.

Ketika interaksi di dalam kelas, guru menemukan peserta didik yang pasif atau ramai pada saat pembelajaran. Sikap guru dalam menyikapi hal ini menjadi penentu dalam perkembangan kepribadian peserta didik salah satunya 
adalah sikap tanggung jawab. Dalam menanggapi hal ini salah satu guru Pendidikan Agama Islam di SMP Negeri 9 menerapkan punishment (hukuman) dengan cara memberikan tugas menghafalkan surat-surat panjang di depan kelas. Adanya hukuman ini mengajarkan pada peserta didik untuk selalu bertanggung jawab dalam setiap perbuatannya. Dengan peserta didik maju ke depan kelas akan menimbulkan rasa malu pada dirinya sehingga berpikir ulang untuk tidak mengulangi kekeliruannya kembali. Selain itu, dengan menghafalkan Al-Quran diharapkan secara spititual dapat merubah sikap peserta didik kearah yang lebih baik lagi. Untuk membentuk sikap sosial peserta didik, guru juga menerapkan pembiasaan pada peserta didik berupa ucapan terimakasih setelah pembelajaran usai. Pembiasaan ini merupakan salah satu kebijakan yang ditetapkan oleh salah satu guru Pendidikan Agama Islam di SMP Negeri 9. Usai pembelajaran, guru mengajarkan pada peserta didik untuk selalu mengucapkan kata terimakasih pada semua guru yang telah memberikan ilmunya. Adanya pembiasaan ini bertujuan untuk membentuk empati dan rasa menghargai pada orang lain dalam diri peserta didik.

SMP Negeri 9 juga mengadakan kegiatan yang merupakan bagian dari pembelajaran PAI di luar kurikulum tertulis seperti kegiatan kajian keputrian di hari Jum'at. Dalam kegiatan ini peserta didik mendapatkan pembelajaran mengenai materi-materi seputar akhlak. Nilai-nilai yang berkaitan dengan toleransi, solidaritas, dan tanggung jawab juga termasuk ke dalam materi pembahasan. Dengan demikian, guru turut memperhatikan akan interaksi yang terjadi di luar pembelajaran kelas dalam membentuk sikap toleransi, solidaritas, dan tanggung jawab peserta didik melalui interaksi yang bersifat edukatif.

Temuan ini sejalan dengan teori Wahid Murni yang dikutip oleh Caswita, yang menyatakan bahwa ada interaksi yang dapat menciptakan peluang terjadinya pengembangan diri yang merupakan bagian dari hidden curriculum PAI, salah satunya adalah interaksi harmonis antara peserta didik dengan guru (Caswita, 2013, p. 124). Demi menciptakan interaksi yang baik dan harmonis dengan peserta didik di luar kelas, maka guru menerapkan prinsip kedekatan pada peserta didik. Dengan adanya kedekatan ini, guru akan memahami peserta didik sehingga dapat membentuk pola interaksi yang saling terbuka. Dalam merealisasikan hal ini, guru maupun kepala sekolah tidak segan untuk melakukan interaksi pada peserta didik ketika mereka memiliki masalah, bisa dilakukan oleh peserta didik itu sendiri, teman dekatnya atau bahkan kepada keluarganya. Dengan melakukan interaksi secara mendalam diharapkan akan terbentuk interaksi yang diinginkan. Sehingga melalui interaksi yang terjalin dengan baik dan harmonis, peserta didik juga akan senantiasa patuh dan taat terhadap perintah dan aturan yang ditetapkan pihak sekolah.

\section{Sistem budaya hidden curriculum PAI}

Sistem budaya merupakan dimensi sosial yang terkait dengan kepercayaan dan nilai-nilai yang ada di sekolah (Rosyada, 2007, p. 30). Lebih lanjut, Hidayat menyatakan bahwa sistem budaya adalah aspek yang mencakup norma sekolah, etos kerja keras, peran, dan tanggung jawab, relasi sosial antar pribadi dan antar kelompok, konflik antar pelajar, ritual dan perayaan ibadah, toleransi, kerja sama, kompetensi, ekspektasi guru terhadap muridnya dan disiplin waktu (Hidayat, 2011, p. 83). Hidden curriculum PAI di SMP Negeri 9 Yogyakarta dimaksudkan untuk menciptakan suasana 
sekolah yang dapat mempengaruhi pembentukan sikap sosial di sekolah dalam aspek budaya dilakukan dengan memperhatikan nilai, prinsip, tradisi, dan pembiasaan-pembiasaan yang terbentuk di lingkungan sekolah. Untuk membentuk budaya sekolah yang baik, pihak sekolah memberikan contohcontoh yang baik seperti keteladanan dan penerapan pembiasaan-pembiasaan pada peserta didiknya. Keteladanan dari guru sangatlah dibutuhkan untuk membentuk sikap peserta didik, di mana peserta didik cenderung untuk meniru apa yang mereka lihat, dengar, dan lakukan oleh orang-orang disekitar mereka. Dalam Pendidikan Agama Islam pun, agar tujuan dalam membentuk budi pekerti peserta didik dapat tercapai, keteladanan menjadi faktor yang utama (Caswita, 2013, p. 107).

Bentuk-bentuk keteladanan di SMP Negeri 9 Yogyakarta yang dicontohkan kepada peserta didik dalam membentuk sikap sosial meliputi: (1) keteladanan sikap dan tingkah laku, (2) keteladanan dalam beribadah dan kepedulian sosial, dan (3) keteladanan dalam disiplin dan peduli lingkungan. Sikap dan tingkah laku guru di sekolah akan selalu menjadi pusat perhatian bagi peserta didik karena guru pasti melakukan interaksi dengan peserta didik baik saat di dalam maupun di luar kelas. Oleh karena itu, guru perlu memperhatikan sikap dan tingkah lakunya di sekolah. Keteladanan guru dalam hal sikap dan tingkah laku di SMP Negeri 9 yakni dilakukan dengan selalu menerapkan senyum, sapa, dan salam serta menerapkan sopan dan santun kepada siapapun. Dengan menerapkan senyum, sapa, dan salam maka akan membentuk rasa kekeluargaan di lingkungan sekolah serta menimbulkan sikap saling menghormati dalam artian menghargai dan menjunjung tinggi harkat dan martabat orang lain. Selain itu guru di sekolah ini juga memperhatikan akan pemilihan bahasa yang sopan dan baik saat berbicara. Keteladanan ini bertujuan untuk mengajak peserta didik agar senantiasa membudayakan senyum sapa dan salam serta membudayakan untuk selalu berperilaku sopan dan santun serta menghormati kepada teman sebaya maupun yang lebih tua.

Keteladanan dalam beribadah dicotohkan oleh guru dengan selalu melaksanakan shalat tepat waktu. Saat bel berbunyi guru bergegas pergi ke mushola atau aula untuk melakukan shalat berjama'ah. Keteladanan ini bertujuan agar peserta didik memiliki semangat untuk melakukan shalat tepat waktu. Selanjutnya guru memberikan contoh untuk senantiasa membantu orang yang sedang membutuhkan. Di SMP Negeri 9, keteladanan guru dalam hal ini ditunjukkan melalui tindakan saling mengunjungi teman-teman yang kesusahan (baru ditimpa musibah) dan sakit, baik itu dari kalangan guru, karyawan, maupun peserta didik. Selain itu, untuk menumbuhkan sikap kepedulian terhadap sesama, guru memberikan contoh dengan selalu beramal/berinfak pada hari Jum'at.

Kedisiplinan merupakan sikap yang sebenarnya memiliki hubungan dalam pembentukan sikap sosial pada diri peserta didik, salah satunya adalah tanggung jawab. Permita Sari menyatakan bahwa, peserta didik yang memiliki rasa tanggung jawab ditunjukkan dengan adanya komitmen yang kuat, disiplin, patuh dan sportif terhadap tugas dan tata tertib (Elviana, 2017, p. 139). Dalam membentuk sikap tanggung jawab pada peserta didik, guru memberikan contoh kepada peserta didik untuk selalu disiplin. Keteladanan pertama yang dicontohkan oleh guru adalah disiplin waktu. Keteladanan ini dilakukan oleh guru dengan memberikan contoh datang tepat waktu pada saat 
pembelajaran di kelas. Sebelum kegiatan doa dimulai, guru sudah duduk di depan kelas menyambut kedatangan peserta didik dengan melakukan salaman. Kemudian disusul dengan peserta didik yang melakukan salaman berjajar secara rapi dan tertib. Selanjutnya keteladanan kepedulian terhadap lingkungan dilakukan dengan cara memberikan contoh secara langsung untuk disiplin dalam menjaga keasrian lingkungan sekolah. Hal ini merupakan salah satu bentuk keteladaan dari guru untuk membentuk sikap tanggung jawab pada lingkungan sekitar (alam). Keteladanan ini dicontohkan dengan cara guru yang selalu membuang sampah pada tempatnya. Guru sering terlihat memungut beberapa sampah yang masih tercecer. Letak ruang guru yang dekat dengan kelas juga dapat menjadikan peserta didik melihat tindakan guru yang selalu membuang sampah pada tempatnya. Dalam melakukan keteladanan ini, guru juga memberikan arahan kepada peserta didik untuk melakukan hal yang sama dan tak segan untuk memberikan teguran secara langsung jika mendapati peserta didik yang masih membuang sampah tidak pada tempatnya.

Keteladanan memiliki unsur penting dalam mengajak orang lain untuk berperilaku sesuai yang dicontohkan. Berkaitan dengan sistem budaya dalam membentuk suasana sekolah yang bernilai, pemberian keteladanan akan kurang efektif bila tanpa diiringi ajakan secara langsung berupa pembiasaan (Sueadi, 2016, p. xi). Menurut Azman (2018), keteladanan yang dicontohkan oleh guru dalam hal beribadah, berbicara, berpakaian, pergaulan, tingkah laku, dan kedisiplinan dapat direalisasikan kepada peserta didik melalui metode pembiasaan. Bentuk- bentuk pembiasaan yang dilakukan di SMP Negeri 9 Yogyakarta meliputi: Pembiasaan salaman pagi, shalat berjamaah, membaca Al-Quran, membaca Asmaul husnō, beramal (infaq dan shadaqah), dan menjaga kebersihan lingkungan sekolah. Pembiasaan salaman pagi berlangsung pada pukul 06.30 hingga pukul 07.00 WIB. Salaman pagi merupakan cerminan dari adanya ikatan kekeluargaan di lingkungan sekolah. Selain itu, salaman pagi juga sebagai bentuk penghormatan dari yang muda pada yang tua dengan cara mencium tangan. Melalui pembiasaan ini guru ingin menanamkan sikap sosial dengan mengajarkan pada peserta didik agar senantiasa menghargai dan menghormati orang yang lebih tua dan menyayangi yang lebih muda sehingga dapat tercipta suasana kekeluargaan dan keakraban.

Pembiasaan melaksanakan shalat berjama'ah merupakan salah satu cara untuk mengaktualkan hidden curriculum Pendidikan Agama Islam. Tentunya dalam pembiasaan ini guru juga ikut serta dalam melaksanakan shalat secara berjama'ah. Terdapat nilai-nilai sosial yang berusaha ditanamkan kepada peserta didik dari pembiasaan shalat secara berjama'ah. Seperti halnya ketika akan shalat, peserta didik diharuskan untuk bersuci (ber-wudhu) terlebih dahulu, saat berwudhu peserta didik akan bersabar untuk mengantri dan ketika bell berbunyi semua diharuskan untuk segera melakukan persiapan menuju tempat shalat. Dalam hal ini ditanamkan sikap disiplin dan tidak ada perbedaan apakah dia peserta didik atau guru semua diharuskan untuk mempersiapkan diri untuk shalat secara berjama'ah.

Pembiasaan membaca Al-Quran dilakukan setiap hari Selasa, Rabu, dan Kamis yang berlangsung selama 15 menit, dimulai dari pukul 07.00 sampai 07.15 WIB. Pembiasaan ini bertujuan untuk membentuk spiritualitas peserta didik sehingga peserta didik yang muslim selalu mencintai Al-Quran 
dan terbiasa untuk membaca Al-Quran di manapun mereka berada. Selain itu, ada tujuan lain yang diharapkan dari pembiasaan ini yakni sikap tanggung jawab. Sehubungan dengan adanya program hafalan juz amma bagi peserta didik baru di SMP Negeri 9, peserta didik diwajibkan agar hafal Juz amma dengan lancar. Masing-masing peserta didik memiliki buku setoran untuk memantau perkembangan hafalannya. Bagi peserta didik yang belum bisa mengejar target maka mereka harus menangung konsekuensi bisa berupa pengulangan atau yang lain, tergantung kebijakan pembimbing. Dengan demikian peserta didik akan bersungguh-sungguh dan tepat waktu dalam menyetorkan hafalannya.

Pembiasaan membaca Asmaul ḥusnō dimaksudkan untuk membiasakan peserta didik mengingat Allah dalam kehidupan sehari-hari. Dengan membiasakan membaca asmaul husna ini juga diharapkan dapat memberikan pengaruh pada sikap peserta didik secara positif baik pada Tuhannya, diri sendiri dan orang lain serta pada lingkungan. Hal ini dikarenakan dengan membiasakan membaca Asmaul husnō, peserta didik diharapkan akan menerapkan apa yang ada dinama- nama Allah. Sebagaimana beberapa nama Allah adalah Ar-rahman dan Ar-rahim yakni maha pengasih dan penyayang, peserta didik diharapkan dapat meneladani sifat Allah melalui Asmaul ḩusnō, yang diketahui bahwa salah satu indikator sifat toleransi adalah cinta damai yang ditunjukkan dengan sikap saling mengasihi dan menyayangi sesama. Hal ini sesuai dengan pendapat Agustian yang menyatakan bahwa kecerdasan spiritual bersumberkan dari suara-suara hati. Dimana, suara hati tersebut ternyata cocok dengan sifat-sifat Ilahiyah yang terekam dalam jiwa manusia. sifat-sifat Ilahiyah yang hadir di jiwa kita selanjutnya akan muncul pada perilaku sehari-hari. Sifat-sifat tersebut di antaranya adalah dorongan ingin mulia, dorongan ingin belajar, dorongan ingin bijaksana, dan dorongan lainnya yang bersumber dari Asmaul husnō. (Agustian, 2008, p. 287).

Pembiasaan untuk beramal (berinfak dan bershadaqah) ini dilakukan agar peserta didik memiliki rasa senang untuk berbagi dengan sesama. Sehubungan dengan pembiasaan ini, uang peserta didik yang terkumpul melalui kegiatan amal tersebut akan digunakan ketika ada warga sekolah yang sakit atau membutuhkan bantuan. Selain itu, sekolah juga memiliki program pembiasaan untuk mengunjungi panti jompo yang dilakukan empat kali selama satu tahun. Pembiasaan ini bertujuan untuk mengajak peserta didik agar memiliki rasa peduli dan membangun kesadaran antar sesama. Tujuan ini berhubungan dengan pembentukan sikap solidaritas pada peserta didik. Dimana, solidaritas menurut Johnson dalam buku Nasution mengartikan sebagai kepedulian secara bersama kelompok yang didasarkan pada perasaan moral, emosional, kolektif yang sama, dan kepercayaan yang dianut (Nasution, 2009, p. 9). Dengan membiasakan peserta didik saling menolong satu sama lain ini, diharapkan peserta didik memiliki empati terhadap penderitaan sesama.

Pembiasaan menjaga kebersihan lingkungan sekolah diarahkan untuk menciptakan lingkungan sekolah yang nyaman dan bersih. Sekolah menerapkan pembiasaan dan tata tertib untuk membuang sampah pada tempatnya. Selain itu pihak sekolah juga membuat rambu-rambu melalui media gambar seperti poster untuk mendukung keberhasilan program tersebut. Pembiasaan ini sesuai dengan ajaran agama Islam yakni annadhafatu minal 
iman. Dengan membiasakan membuang sampah pada tempatnya diharapkan akan membentuk perilaku disiplin dan tanggung jawab pada diri peserta didik.

Berdasarkan pemaparan hasil penelitian di atas, menunjukkan bahwa pembelajaran PAI di SMP Negeri 9 Yogyakarta tidak hanya dilaksanakan melalui rancangan kurikulum ideal yang tertulis secara jelas dan formal, akan tetapi juga dapat dilakukan di luar kelas yang tergambar dalam sistem organisasi, sosial, maupun budaya bertujuan untuk membentuk suasana sekolah yang damai, bersih, asri, dan nyaman untuk dijadikan tempat belajar sehingga memberikan pengaruh dalam pembentukan sikap peserta didik. Semakin konsisten ketiga sistem tersebut terpelihara dalam konsep-konsep idealnya, maka akan semakin besar peluang sekolah untuk dapat mencetak peserta didik sesuai dengan tujuan pendidikan nasional, yakni peserta didik yang berbudi pekerti luhur (Rosyada, 2007, p. 29).

\section{Implikasi Hidden Curriculum PAI dalam Membentuk Sikap Sosial Peserta didik}

Hidden curriculum Pendidikan Agama Islam (PAI) dapat memberikan dampak bagi perubahan sikap peserta didik. Pendidikan Agama Islam yang secara umum berisikan tentang aspek tauhid, syariat dan akhlak ini sangat relevan jika dikaitkan dengan hidden curriculum (Mustaghfiroh, 2014, pp. 149-150). Dengan meng-aktualkan hidden curriculum PAI melalui proses yang berlangsung pada sistem organisasi, sosial, dan budaya di SMP Negeri 9 Yogyakarta ini ikut andil dalam membantu tercapainya tujuan dari pembelajaran PAI yakni untuk menjadikan hamba yang taat kepada Tuhannya dan saling menghormati antar sesama.

Sistem organisasi di SMP Negeri 9 Yogyakarta yang menerapkan prinsip keadilan/pemerataan dalam melakukan pengelompokan rombongan belajar berdasarkan kemampuan yang dimiliki masing-masing peserta didik, pembagian tugas mengajar guru secara profesional, serta adanya perhatian terhadap kompetensi sikap dalam penentuan kenaikan kelas, dapat memberikan kontribusi dalam membentuk sikap sosial peserta didik. Peserta didik mendapatkan pembelajaran yang sesuai dari guru yang kompeten menguasai materi pembelajaran. Pada sistem pengelompokan, peserta didik akan merasa diperlakukan secara adil dalam kebijakan yang diterapkan. Selain itu, peserta didik juga akan memperhatikan sikapnya selama di sekolah demi kelangsungan kenaikan kelas mereka.

Hubungan interaksi yang berjalan secara harmonis di sekolah membentuk sikap saling menghormati terhadap orang lain (teman dan guru). Guru yang selalu menerapkan prinsip persamaan, kedekatan dan persaudaraan dalam proses interaksi turut mempengaruhi pola pertemanan dan interaksi untuk saling menghargai, menghormati, dan tidak memandang kekurangan sesama peserta didik. Proses interaksi yang harmonis ini nampak pada hubungan antara peserta didik yang seagama maupun berbeda agama dengan tidak menggangu satu sama lain, tidak pilih-pilih teman dan berteman dengan baik. Pola hubungan yang demikian ini mengandung nilai toleransi, di mana menurut pendapat Maragustam, toleransi diartikan sebagai sikap saling berbuat baik kepada setiap orang, baik yang berbeda ataupun sama dengan pendirian yang dia miliki, menolong orang lain yang membutuhkan, menjalin persaudaraan dan kekerabatan dengan yang lainnya (Maragustam, 2018, p. 282). Nilai-nilai toleransi dalam hubungan antar peserta didik yang harmonis ini termasuk ke dalam prinsip umat (ummah), dan prinsip persatuan dan persaudaraan. Prinsip umat adalah prinsip untuk hidup 
bersama, secara berdampingan, dan mengikat hubungan sosial dalam sebuah kelompok, komunitas, masyarakat atau bangsa (Assegaf, 2011, p. 313). Prinsip persatuan dan persaudaraan merupakan prinsip untuk memiliki rasa persatuan dan persaudaraan kemanusiaan seagama maupun persatuan dan persaudaraan antar pemeluk agama (Pohan, 2014, p. 94). Sesuai dengan pendapat tersebut, bahwa sistem sosial sebagai bagian hidden curriculum memberikan pengaruh dalam pembentukan sikap sosial salah satunya adalah toleransi antar sesama.

Sistem budaya yang dilaksanakan di SMP Negeri 9 Yogyakarta juga berimplikasi pada pembentukan sikap sosial peserta didik. Melalui budaya senyum, sapa, dan salam ketika bertemu guru dan teman-temannya serta, saat diterapkan dalam kegiatan salaman pagi dapat membentuk sikap saling menghormati dalam diri peserta didik. Senyum, sapa, dan salam merupakan ciri kepedulian antar sesama dan rasa hormat kepada orang lain atas keberadaannya. Melalui senyum, sapa, dan salam akan membentuk ikatan batin dengan orang yang bersangkutan dan akan timbul rasa untuk melindungi satu sama lain (Pondok Ilmu Nusantara). Budaya ini menjadikan suasana kekeluargaan di sekolah sehingga mempengaruhi hubungan sosial yang terjadi antara peserta didik dengan guru dan sesama teman sebayanya. Keterlibatan peserta didik dalam mengambil keputusan yang merupakan gambaran dari sistem sosial hidden curriculum PAI menjadikan peserta didik lebih terbuka dalam menyampaikan pendapatnya. Kebijakan guru dalam menyikapi peserta didik yang ramai. Guru memberikan hukuman yang sesuai kepada peserta didik ketika peserta didik tidak memperhatikan saat proses belajar berlangsung. Adanya kebijakan guru dalam menyikapi peserta didik ini kemudian menjadikan peserta didik lebih sportif dan bertanggung jawab atas segala perbuatan yang telah dilakukan.

Sistem budaya yang memberikan kultur untuk bersikap jujur. Sikap jujur adalah hasil lain dari adanya sikap tanggung jawab. Sama seperti tanggung jawab, jujur juga terbentuk dari sistem sosial dan budaya di sekolah melalui teguran, nasihat, dan pembiasaan. Sikap jujur pada peserta didik di SMP Negeri 9 ini antara lain ditunjukkan dengan peserta didik yang selalu mengembalikan barang temuan berupa uang, flashdisk, tuperware, dan lain-lain pada pihak yang berwenang. Peserta didik menuliskan barang temuan ke dalam buku dan memberikannya kepada salah satu petugas TU. Bagian lain dari system budaya yang dilatihkan di SMP Negeri 9 Yogyakarta adalah budaya disiplin. Disiplin merupakan sistem budaya yang digunakan sebagai panduan dalam berlangsungnya hidden curriculum PAI di sekolah. Melalui sistem budaya ini, sekolah berusaha membentuk tradisi dan aturan yang bertujuan untuk membentuk sikap disiplin bagi peserta didik yakni dengan cara memberikan hukuman bagi peserta didik yang datang terlambat ke sekolah dan guru memberikan contoh secara langsung untuk selalu datang tepat waktu baik saat datang ke sekolah maupun saat akan memulai pelajaran di dalam kelas.

Pembudayaan kedisiplinan di sekolah ini kemudian menanamkan rasa malu dan takut jika peserta didik datang terlambat sehingga peserta didik terbiasa untuk datang tepat waktu. Disiplin merupakan hal yang dapat mempengaruhi sikap peserta didik dalam belajar yakni salah satunya adalah sikap tanggung jawab. Menurut pendapat Permita, peserta didik memiliki tanggung jawab pribadi yang berkaitan dengan kegiatan belajar yang dilakukan. Di antara bentuk sikap tanggung jawab tersebut ditunjukkan dari komitmen (rasa sunguh-sungguh) peserta didik pada tugas yang diberikan, memiliki kedisiplinan dalam mengikuti kegiatan belajar mengajar, patuh pada tata tertib dan sportif ketika melaksanakan 
tugas dari guru (Elviana, 2017, p. 139). Berdasarkan pendapat tersebut maka guru yang memberikan keteladanan dalam disiplin waktu telah memberikan kontribusi dalam pembentukan sikap tanggung jawab pada peserta didik melalui komitmen atau rasa bersungguh- sungguh sebagai seorang peserta didik untuk mengikuti kegiatan pembelajaran. Selain itu, adanya budaya disiplin ini juga telah mempengaruhi peserta didik dalam menaati aturan, salah satunya adalah menerapkan kerapian dan kebersihan. Ketika datang ke sekolah, peserta didik memasuki gerbang secara tertib dan memarkirkan sepeda yang mereka gunakan secara rapi. Peserta didik secara sadar selalu menerapkan kerapian menunjukkan bahwa dirinya telah patuh pada tata tertib yang diberlakukan di sekolah. Selanjutnya, sikap tanggung jawab peserta didik juga terbentuk melalui pembiasaan dalam membuang sampah pada tempatnya. Pembiasaan ini menjadikan peserta didik sadar akan tanggung jawabnya dalam menjaga kebersihan lingkungan sekolah. Perilaku peserta didik yang terbiasa membuang sampah pada tempatnya ini kemudian menjadi kultur di sekolah sehingga lingkungan sekolah menjadi bersih.

Sistem budaya yang berjalan melalui pembiasaan untuk ber-amal. Pembiasaan ini bertujuan untuk melatih dan mengajarkan kepada peserta didik untuk ikhlas serta rela dalam menginfakkan sebagian uang sakunya dan juga mengajarkan akan pentingnya menolong orang yang sedang mengalami kesusahan sehingga mampu menumbuhkan rasa empati pada diri peserta didik dan membentuk rasa peduli satu sama lain. Bentuk kepedulian juga terlihat pada kegiatan donasi yang dilakukan oleh peserta didik SMP Negeri 9 di mana mereka secara bersama-sama menyisihkan uang sakunya untuk di donasikan ke Palestina melalui ACT, serta secara berkala/insidensial berdonasi kepada orang-orang yang terkena musibah seperti gempa dan kunjungan bakti sosial ke panti jompo.

Selain itu, peserta didik juga memiliki sikap peduli kepada sesama ketika mendapati orang yang kesusahan maka mereka tidak segan untuk memberikan sebagian uang sakunya. Adanya pelaksanaan hidden curriculum PAI di sekolah ini juga memberikan pengaruh dalam membentuk sikap tolong menolong antar sesama. Hal ini tampak pada kebiasaan peserta didik yang tidak segan untuk menolong temannnya seperti membagi bekal makanan, bekerja sama membersihkan ruangan shalat, bersama-sama membawa bingkisan untuk diletakkan pada aula dan mushola saat Jum'at berkah, serta melakukan kunjungan langsung apabila ada salah satu warga sekolah yang sedang sakit atau berduka dengan memberikan bantuan melalui do'a dan bantuan biaya yang telah dikumpulkan secara bersama- sama oleh warga sekolah. Dengan saling peduli, senang membantu orang lain (tolong-menolong), gotong royong dan bekerjasama dalam menjaga kebersihan lingkungan sekolah mencerminkan sikap solidaritas, sebagaimana yang dikatakan oleh Shadily, bahwa orang yang memiliki sikap solider ditunjukkan dengan sikap suka bekerjasama dan gotong royong (Shadily, 1993, p. 205). Hal ini juga sesuai dengan pendapat Boisard yang menyatakan, seseorang dikatakan memiliki sikap solidaritas apabila ia menunjukkan sikap saling tolong menolong, berkerjasama, saling berbagi dan kasih sayang serta mengesampingkan perbedaan sehingga menganggap bahwa dirinya tidak berbeda dengan yang lain (Boisard, 1980, p. 142).

\section{KESIMPULAN}

Pelaksanaan hidden curriculum PAI untuk membentuk sikap sosial peserta didik di SMP N 9 Yogyakarta diwujudkan dalam bentuk penerapan sistem 
organisasi, sistem sosial, dan sistem budaya. Penerapan sistem organisasi dengan cara menerapkan prinsip keadilan/pemerataan dalam pengelompokan rombongan belajar/pembagian kelas, pembagian tugas mengajar guru secara profesional untuk memberikan pelayanan akademik yang terbaik, serta adanya perhatian terhadap kompetensi sikap dalam penentuan kenaikan kelas peserta didik. Penerapan sistem sosial diwujudkan dalam bentuk membangun interaksi/hubungan guru dengan peserta didik yang berjalan secara harmonis yang dilakukan dengan cara bersikap sederajat dengan menerapkan prinsip persamaan dan persaudaraan. Hal ini dimaksudkan untuk mewujudkan perasaan saling menghormati, menghargai, dan tidak memandang orang lain sebelah mata, membentuk kepercayaan diri peserta didik, guru memposisikan diri sebagai orang tua dan teman dekat peserta didik, menjadikan pembelajaran yang menyenangkan, bijak dalam menyikapi peserta didik yang ramai, tidak memihak dan menghakimi dan memberikan kesempatan bagi peserta didik untuk memperbaiki diri. Penerapan sistem budaya diwujudkan dalam bentuk menciptakan budaya sekolah yang baik dengan memperhatikan nilai, prinsip, tradisi, dan memberikan contohcontoh yang baik seperti keteladanan serta menerapkan pembiasaan-pembiasaan pada peserta didik, seperti pembiasaan untuk membudayakan 5S (senyum, sapa, salam, sopan, dan satun), membiasakan untuk shalat berjama'ah, membaca Asmaul hususnā dan tadarus Al-Qur'an, disiplin, berinfak, mengunjungi teman yang sakit, dan membuang sampah pada tempatnya.

Pelaksanaan Hidden curriculum PAI di SMP Negeri 9 Yogyakarta berimplikasi terhadap pembentukan sikap sosial peserta didik yang ditunjukkan dengan sikap saling menghormati orang lain, tidak pilih-pilih dalam hal pertemanan, membudayakan senyum, salam, dan sapa pada semua orang, jujur, disiplin, bertanggung jawab, saling menolong teman yang sedang membutuhkan, dan peduli pada sesama.

\section{DAFTAR PUSTAKA}

Abdullah, A. (1998). Problem Epistimologis Metodologis Pendidikan Islam. Pustaka Pelajar.

Agustian, A. G. (2008). Rahasia Sukses Membangun Kecerdasan Emosi dan Spiritual. Arga Publishing.

Asrori, M. (2019). Direktur PAI: Bukan Hal Sederhana Menghapus Pendidikan Agama. Nu Online. https://www.nu.or.id/post/read/108628/direktur-paibukan-hal-sederhana menghapus-pendidikan-agama.

Assegaf, A. R. (2011). Filsafat Pendidikan Islam. Raja Grafindo.

Azman, Z. (2018). Urgensi Keteladanan Guru Pendidikan Agama Islam dalam Memebnetuk Akhlak Siswa. El-Ghiroh, 15(1).

Boisard, M. A. (1980). Humanisme dalam Islam. Bulan Bintang.

Caswita. (2013). The Hidden Curriculum: Studi Pembelajaran PAI di Sekolah.LutikaPrio.

Cholisoh, L. (2019). Analisis Implementasi Hidden Kurikulum dalam Pendidikan Karakter: Studi Kasus SD Islam Al-Syukro Universal Kota Tanggerang Selatan. Universitas Islam Negeri Syarif Hidayatullah.

Creswell, J. W. (2014). Penelitian Kualitatif dan Desain Riset: Memilih Diantara Lima Pendekatan, terj. Ahmad Lintang Lazuardi. Pustaka Pelajar.

Darmadi, H. (2013). Metodologi Penelitian Pendidikan dan Sosial. Alfabeta.

Elvania, P. S. O. (2017). "Pembentukan Sikap Mandiri dan Tanggung Jawab Melalui Penerapan Metode Sosiodrama dalam Pembelajaran Pendidikan 
Kewarganegaraan.” Jurnal Pancasila Dan Kewarganegaraan, 3(1).

Fariha, I., \& Nurani, I. (2017). Internalisasi Nilai-Nilai Keislaman dalam Skema Hidden Curriculum di MTS Nurul Huda Medini Demak. Edukasia, 12(1).

Fu'adi, A. (2016). Peran Pendidikan Agama Dalam Membentuk Manusia Yang Berkeadaban Publik. Millah, XI(2), 559-578. https://doi.org/10.20885/ millah.volxi.iss2.art11.

Hawi, A., \& Khoiri, Q. (2017). Arah Pengembangan Pendidikan Agama Berwawasan Multikultural. Intizar. https://doi.org/10.19109/intizar.v23i1.

Hidayat, R. (2011). Pengantar Sosiologi Kurikulum. Raja Grafindo.

Indrawan, I. (2016). Pendidikan Karakter dalam Perspektif Islam. Al-Afkar: Jurnal Keislaman \& Peradaban, 2(1). https://doi.org/10.28944/afkar.v2i1.90.

Khuzaimah. (2018). Implementasi Nilai-Nilai Pendidikan Multikultural dalam Pembelajaran PAI (Telaah Terhadap Hidden Curriculum di SMAN 1 dan SMAN 2 Grabag Tahun 2018). IAIN Salatiga.

Lubis, A. F. (2015). Hidden Curriculum dan Pembentukan Karakter (Studi Kasus di Madrasah Aliyah Pembangunan UIN Jakarta. Universitas Islam Negeri Syarif Hidayatullah Jakarta.

Malihah, E., Maftuh, B., \& Amalia, R. (2015). Tawuran Pelajar: Solidarity in the Student Group and its Influence on Brawl Behaviour. Komunitas: International Journal of Indonesian Society And Culture. https://doi.org/10.15294/komunitas.v6i2.3301.

Manizar, E. (2018). Optimalisasi Pendidikan Agama Islam di Sekolah. Tadrib: Jurnal Pendidikan Agama Islam. https://doi.org/10.19109/tadrib.v3i2.1796.

Maragustam. (2018). Filsafat Pendidikan Islam Menuju Pembentukan Karakter. Pascasarjana Fakultas Ilmu Tarbiyah dan Keguruan (FITK) UIN Sunan Kalijaga.

Margono, S. (2010). Metodologi Penelitian Pendidikan. Rineka Cipta.

Maryani, I., \& Fitria. (2018). Pelaksanaan Hidden Curriculum pada Mata Pelajaran Al-Islam di Sekolah Dasar. Edu Humaniora, 10(1).

Masykur, H. (2015). Eksistensi dan Fungsi Pendidikan Agama Islam dalam Sistem Pendidikan Nasional [IAIN Salatiiga]. http://erepository.perpus.iainsalatiga.ac.id/618/1/Hanif Masykur_11412004.pdf.

Miles, M. B., \& Huberman, M. A. (1994). Qualitative Data Analysis: A Expanded Sourcebook (Second Edi). Sage Publications, Beverly Hills.

Moloeng, L. J. (2014). Metode Penelitian Kualitatif. Remaja Rosdakarya.

Mustaghfiroh,H.(2014). Hidden Curriculum dalam Pembelajaran PAI. Edukasia: Jurnal Penelitian Pendidikan Islam. https://doi.org/10.21043/ edukasia.v9i1.769.

Nasution. (2003). Metode Penelitian Naturalistik Kualitatif. Tarsito.

Nasution, Z. (2009). Solidaritas Sosial dan Partisipasi Masyarakat Desa Transisi. UMM Pres.

Novitasari, P. (2017). Peran guru dalam Pelaksanaan Hidden Curriculum terhadap Pencapaian Tujuan Pendidikan Agama Islam di MAN 1 Bandarlampung. Journal of Chemical Information and Modeling. https://doi.org/10.1017/CBO9781107415324.004.

Pohan, R. A. (2014). Toleransi Inklusif: Menapak Sejarah Kebebesan Beragama dalam Piagam Madinah. KAUKABA DIPANTARA.

Pratiwi, E. R. (2018). Pengaruh Hidden Curriculum terhadap Pembentukan 
Karakter Siswa Di SMP IT Masjid Syuhada' Kotabaru Yogyakarta. Jurnal Pendidikan Agama Islam. https://doi.org/10.14421/jpai.2017.142-04.

Rosyada, D. (2007). Paradigma Pendidikan Demokratis. Kencana Prenada Media Group.

Sanjaya, W. (2009). Penelitian Tindakan Kelas. Kencana Prenada Media Group. Sardiman. (1986). Interaksi dan Motivasi Belajar Mengajar. Rajawali.

Sarwono, R. B. (2017). Mengendalikan Kegaduhan Sosial "Klithih" Dengan Ketahanan Keluarga. Proceeding Seminar Dan Lokakarya Nasional Revitalisasi Laboratorium Dan Jurnal Ilmiah Dalam Implementasi Kurikulum Bimbingan Dan Konseling Berbasis Kkni. https://doi.org/10.1111/j.1365-2958.2005.04830.x

Shadily, H. (1993). Sosiologi untuk Masyarakat Indonesia. Rineka Cipta. Su'dadah, S. (2014). Kedudukan dan Tujuan Pendidikan Agama Islam di Sekolah.

Jurnal Kependidikan, 2(2), 143-162. https://doi.org/10.24090/jk.v2i2.557.

Suaedi. (2016). Membangun Kota Berkelanjutan (I. Press (ed.). Sugiharjo. (2019). Hasil Wawancara. SMP Negeri 9 Yogyakarta.

Sugiyono. (2016). Metode Penelitian Pendidikan (Pendekatan Kuantitatif, Kualitatif, $R \& D)$. Alfabeta.

Sukiman. (2015). Pengembangan Kurikulum Perguruan Tinggi. Remaja Rosdakarya.

Sukmadinata, N. S. (2010). Metode Penelitian Pendidikan. Remaja Rosdakarya.

Susiana, S. (2017). Problematika Pembelajaran PAI di SMKN 1 Turen. Jurnal Pendidikan Agama Islam Al-Thariqah. https://doi.org/10.25299/ althariqah.2017.vol2(1).648.

Suyanto, B. (2005). Metode Penelitian Sosial Berbagai Alternatif Pendekatan. Prenada.

Tjongjono, B., Gunardi, H., Pardede, S. O., \& Wiguna, T. (2019). Perundungansiber (Cyberbullying) serta Masalah Emosi dan Perilaku pada Pelajar Usia 12-15 Tahun di Jakarta Pusat. Sari Pediatri. https://doi.org/10.14238/ sp20.6.2019.342-8.

Utami, Y. C. (2014). Cyberbullying di Kalangan Remaja. Universitas Airlangga.

Viral Guru Dianiaya, Apakah Peran Pengajar Sudah Berubah? Kompas. Com. https://www.kompas.com/tren/read/2019/09/08/172626165/viralguru-dianiaya-apakah-peran-pengajar-sudah-berubah?

Waliyanti, E., Kamilah, F., Fitriansyah, R. R., Studi, P., Keperawatan, (2018). Fenomena Perilaku Bullying pada Remaja di Yogyakarta. Jurnal Ilmiah Keperawatan Indonesia. https://doi.org/ISSN: 2580-3077.

Yaqin, A. (2011). Efektivitas Pembelajaran Afeksi di Madrasah/Sekolah. Islamica, 6(1). 